\title{
Executive catalysts: predicting sustainable organizational performance amid complex demands
}

Article

Accepted Version

Akrivou, K. and Bradbury-Huang, H. (2011) Executive catalysts: predicting sustainable organizational performance amid complex demands. The Leadership Quarterly, 22 (5). pp. 995-1009. ISSN 1048-9843 doi:

https://doi.org/10.1016/j.leaqua.2011.07.019 Available at https://centaur.reading.ac.uk/19956/

It is advisable to refer to the publisher's version if you intend to cite from the work. See Guidance on citing.

To link to this article DOI: http://dx.doi.org/10.1016/j.leaqua.2011.07.019

Publisher: Elsevier

All outputs in CentAUR are protected by Intellectual Property Rights law, including copyright law. Copyright and IPR is retained by the creators or other copyright holders. Terms and conditions for use of this material are defined in the End User Agreement.

www.reading.ac.uk/centaur 
Central Archive at the University of Reading

Reading's research outputs online 


\title{
Executive Catalysts:
}

\section{Predicting Sustainable Organizational Performance amid Complex Demands}

\author{
(forthcoming, 2011), Leadership Quarterly.
}

Kindly check with the authors updated info on forthcoming publication details before using this as a reference.

\section{Authors:}

\section{KLEIO AKRIVOU ${ }^{1}$, PH.D.}

Assistant Professor in Organizational Behavior and Management,

School of Management, Henley Business School, University of Reading

Whiteknights, Reading, RG6 6UD United Kingdom

Telephone: $+44(0) 1183788226$ +44(0) 7538076353

K.Akrivou@henley.reading.ac.uk

\author{
HILARY BRADBURY-HUANG, PH.D. \\ Professor of Management \\ Division of Management \\ Oregon Health \& Sciences University \\ Portland, OR 97239 \\ bradbury@ohsu.edu
}

${ }^{1}$ Corresponding Author 
Executive Catalysts: Predicting Sustainable Organizational Performance Amid Complex Demands 


\title{
Executive Catalysts:
}

\section{Predicting Sustainable Organizational Performance amid Complex Demands}

\begin{abstract}
We propose a conceptual model to better understand core capacities that equip some executives to be effective catalysts of organizational performance over time. Drawing on constructivist theory of ego development, we suggest that the combined effects of self differentiation/complexity and self-integration are individual level predictors of being an effective catalyst. We assert that capacity for meaning making at the individual level is a prerequisite for the type of sense giving that coordinates stakeholder actions. From coordinated action outstanding leadership performance becomes possible. We link our contribution with leadership theory on the importance of vision and complexity. We offer measures and propositions to support empirical testing. We also address directions and implications for further research with emphasis on how executives may develop these capacities.
\end{abstract}

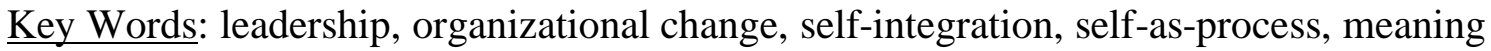
making, vision, mental models, sensemaking, leader development, complexity leadership, organizational sustainability. 
This paper's primary task is identifying and describing psychological capacities that help executives effectively respond to complex demands for organizational performance. Our work is animated by the metaphor (Morgan, 1986) of the executive as catalyst — an individual who creates conditions that foster others' engagement. The article contributes to a better understanding of why some in formal positions of power are successful catalysts of organizational performance over time, and are able to respond to environmental and multi-stakeholder demands where others remain unable to move their organizations much beyond the status quo.

Our question is posed at a time when executives face increasingly complex demands (Waddock, 2007; 2008) of corporate performance and responsibility, i.e. to address financial, social, technical and environmental concerns (Mumford et al, 2000; Paine, 2003) in a sustainable manner. Others have observed that the requirements of executive success appear to be steadily morphing from achieving the one dimensional task of increasing shareholder value to the multi-dimensional tasks of managing complex processes (Brown \& Trevino, 2006; Ciulla, 1995) of stakeholder engagement (Doh \& Stumpf, 2005; Maak, 2007; Maak \& Pless, 2006). Responding to complex demands necessarily requires a higher degree of inclusivity, engagement and consultation with more varied stakeholders than was required by a traditional executive portfolio.

As executives respond to multiple, sometimes conflicting, demands, technical, behavioral and strategic dynamics intersect (Roth \& Senge, 1996). Such an interplay of complex dynamics was on display during the 2009 public scrutiny of the U.S. automotive industry. Some politicians demanded that in return for taxpayer bailout money, the manufacturers must develop sustainable cars that would move Americans away from 
"addiction to fossil fuel." The directive for technical innovation around gas consumption obviously placed new demands on executives in the targeted companies. In addition, it came in the context of global economic/financial uncertainty, compounded by strategic and behavioral uncertainty resulting in part from a history of adversarial negotiations with a unionized workforce in a highly politicized context. Strategic action would reverberate through a global network and require response (including resignation) from many organizational leaders. In this paper we seek primarily to account for the individual prerequisites of leadership performance in similarly complex circumstances. In our account we also include appreciation for the emergent dynamics of others' leadership. Leadership performance is assumed, therefore, to be predicated on meeting explicit organizational goals such as board mandated organizational (profit) targets. Additionally, and though more ill defined, responding successfully to emergent and shared goals of key stakeholders is a critical element of achieving such success over time and often results in emergent leadership among many others. We suggest that enabling cooperative dynamics allows organizational performance over time.

Two lines of leadership theory support the goals of this paper. We draw from theory on the dynamics of vision (Mumford \& Strange, 2002), which holds that outstanding leader performance stems from the degree to which mental models successfully crystallize system goals; we also draw from complexity leadership theory (Marion \& Uhl-Bien, 2001; Uhl-Bien et al., 2007) which posits that performance success depends upon the degree to which networks of interdependent agents can bond in cooperative dynamics. 
We reason that a capacity for complex and integrative meaning making is increasingly essential for successful leaders. Our contribution is to theorize that these are empirically measurable capacities that are the product of a particular ego structure. This structure enables an executive to engage in the communications and actions needed to succeed in the context of today's complex performance demands. Ego is a fundamental psychological concept of personality organization. Ego is the mechanism that synthesizes internal and external personal reality and, more generally, orchestrates individual perception and construction of reality by coordinating affect, thought and action (Loevinger, 1976). Adult ego development theory views ego as the fundamental mechanism that strives for meaning and integration in humans (Fingarette, 1963). Within ego psychology, constructive developmental theory has been used to advance understanding of executive performance (McCauley et al., 2006).

A constructivist approach informs our theory of self which, in turns, allow us to assert a link between executive meaning making and the capacity to articulate a message that both locates the self amid complexity (Akrivou, 2009; Kegan, 1994; Kegan \& Laskow, 2009) and engages others (Cook-Greuter, 1999). These capacities fuel effective executive leader action (Akrivou, 2009; Kegan, 1994; Perry, 1999; Rogers, 1961; Torbert, 1994; Torbert et al., 2004). We focus, therefore, on explaining the links between executives' ego structure and the sensemaking that happens as a consequence. Critical to leaders is the ability to posit an accurate model of situational dynamics. We argue that it is a leader's sensegiving that enables him or her to abstract compelling models. From the resulting sensegiving process effective organizational leadership emerges. We, therefore, bring special attention to the variables prerequisite to the 
process of sensemaking: complexity/differentiation and self-integration. Our work therefore also responds to the call for more research on the micro dynamics of sensemaking and sensegiving in organizational change (Gioia \& Chittipeddi, 1991).

The paper proceeds as follows: First, we ground our contribution by summarizing relevant research on the dynamics of vision and leadership. Second, we argue that success of executive catalysts originates in the executive self-system and discuss why constructivist theory of ego development offers a useful theoretical perspective. Third, we introduce, define and illustrate the focal capacities—self differentiation/complexity and self-integration — that predict executives' ability to be catalysts. We then employ complexity leadership theory to suggest how executives can use these capacities to engage stakeholders. Fourth, we offer testable propositions. Fifth, we address critique in the literature about the difficulty of measuring some of these capacities by offering operational definitions for each. We end with directions and implications for future inquiry, including scholarship and practice with regard to executive development.

The Executive Leader: Catalyst for Others' Leadership.

Scholars of leadership increasingly assume that the executives' activity occurs in conditions of change and turbulence (Mumford, 2006, Paine, 2003). They have come to argue that leadership itself must be explained as much as the traits of individual leaders. A valid leadership model therefore needs to account for the capabilities throughout an 
organization that solve significant organizational and related social problems (Mumford et al, 2000).

We find the metaphor of catalyst a helpful hybrid between the notions of transformational architect and ideological "hero". The catalyst clearly uses the formal power that gives the executive a position from which to be a convener of leadership, responsible for the translation of change (Clegg et al., 2006) and the engagement of sense making activities (Weick, 1995) that enable and nurture collective action. We argue that the emergence of leadership among others is itself a product of leaders grounded in requisite ego development that allows for overall transformational catalysis.

The view of the executive as catalyst highlights the role of executive vision in complex systems. Specifically, aiming at integrating various kinds of outstanding leadership -namely, charismatic, ideological and pragmatic- (Mumford et al, 2008)—we theorize that a catalytic leader's articulation of future oriented visions predicts "outstanding performance" in meeting organizational goals. Such articulated visions translate into acts of sensegiving (Mumford et al., 2008; Mumford \& Strange, 2002) that orient and motivate stakeholders by providing them a sense of meaning and inspiring their effective engagement (Bass, 1990) and moves stakeholders toward a prescribed and idealized state (Strange \& Mumford, 2005). The same theory proposes that a vision not only aims to explain a leader's own view of a future, but also, simultaneously, articulates and constructs the values, purposes and identities (Strange \& Mumford, 2005) for various stakeholders (Mumford \& Strange, 2002).

We present a process model that explains how a catalytic executive can transform business as usual from a number of independent actors into an ensemble undertaking 
collective action. This type of transformation has been described as a metanoia (Senge, 1990) from Greek 'meta' (beyond) and 'noisis' (derivative of "nous," rational mind), a transcendence of the leader's capacities emanating from the rational mind. To catalyze this shift of mind the executive needs the ability to work with followers' frameworks and identities, expanding horizons of understanding of the complex change needed (Gadamer, 1965, Riceour, 1976) and utilizing available talent and knowledge. Constructivist developmental theory draws attention squarely to the evolution of executive "meaning making," i.e., the overlapping aspects of human experiences: cognition, affect, self-concept, and relationships with others (McCauley et al., 2006). Furthermore, scholars within the constructive developmental paradigm (Cook-Greuter, 1999; Kegan, 1994, Kegan \& Laskow, 2009; Torbert et al., 2004) have focused on discerning links between conceptual frames of reference and capacity to align others in strategic action.

The Constructivist Approach and Intrapersonal Antecedents

Constructivist adult development theory focuses particularly on what individuals are able to reflect upon (Loevinger, 1976) and as a consequence impact change (Akrivou, 2009; Cook-Greuter, 1999). Thus, this theory offers a causal link between a person's way of knowing and the impact the person has on others (Kegan, 1994; Kegan \& Laskow, 2009; Torbert \& colleagues, 2004).

Constructive developmental theory provides two key constructs that independently allow for movement from simpler to more complex forms of meaning 
making: self-complexity/differentiation and self integration. Central to the work of Kegan (1982; 1994), Kegan and Laskow (2009), Torbert and colleagues (2004), Bartone et al, (2007) is the implication that executives with capacity for more complex and integrative meaning making are better at catalyzing change. Thus the more complex and integrated is the continuum of meaning making, transformative action and performancewhat Torbert (1994) refers to as a person's 'action logic' — the more measurably successful the person is likely to be at performing complex tasks and meaning making. On the other hand, less complex and less integrated action logics lead to measurably less success at transformative action, thus impeding executive and, consequently, organizational performance over time (Rooke \& Torbert, 2005).

We assert that the kind and quality of an executive's meaning making (as crystallized by a vision) is reflected sensegiving ability. Figure 1 diagrams the core features of our thesis. We assert also that the intrapersonal deep structure variables of self differentiation/complexity and self integration yield capacity for complex and integrative meaning making in the self. In turn, capacity for sensegiving engages broad stakeholder engagement. We next turn to the role of self-complexity/differentiation and selfintegration.

INSERT FIGURE 1 ABOUT HERE

Key intra-personal capacities for executive catalysis of outstanding performance 
The variables that explain executive meaning making combine (a) conceptual and relational complexity that transcends either/or polarizations and enables complex sensemaking and sensegiving action and (b) capacity for strategic commitment; (c) unswerving focus in the face of competing goals, value sets and agendas, informed by an internal set of ethical principles; and (d) active engagement in the processes of consensus building, i.e., a 'win-win' orientation to achieve strategic goals for communication of the vision to a clear and evolving collective identity that has the power to produce organizational performance. Next we introduce the rationale for proposing each variable's distinct role, offer operational definitions and then move on to discuss their combined effects.

\section{Self-complexity / differentiation}

Described as the degree to which a person displays cognitive and psychosocial complexity, self-complexity/differentiation is comprised of thought patterns, emotions, and self-concepts (Johnson, 2000). It is part of being able to act amid a web of complex relationships and allows the individual to cope with complex demands faced in the social world (Kegan, 1994; Lahey, 1986). Thus, increased complexity/differentiation involves an executive's breadth and depth of roles and memberships. The ability to understand complexity is embedded in personality structures that constitute systems of meaning making, which naturally differ in content among individuals.

Complexity is also related to general intelligence, a capacity that is seen to be usually higher among leaders than in the general population (Bass, 1990). In terms of 
how such intelligence is manifested, includes the ability to move away from simplistic thinking as well as the avoidance of rigid and narrow self-other categorizations by employing a diverse and rich number of personal constructs, (for review, see Akrivou, 2009). These are reflected in the action produced, i.e., an executive's ability to perform in response to complex challenges. Thus, an increase of differentiation positively impacts the executive's ability to appreciate a complex business mandate (Bartunek et al., 1983; for review also, McCauley et al., 2006) that involves both the context of action as well as the system within which it is performed. Complexity of self increases an executive's ability to avoid dogmatic thinking (Perry, 1999), and narrow self-categorizations (Akrivou, 2009; Johnson, 2000). The ability to understand, in turn, is enabled by shifts in cognitive and psychosocial perspectives. Complexity therefore enables construction of mental models that include competing stakeholders. It has also been observed to enable tolerance of greater ambiguity (Bartunek et al., 1983; 1999) and stress (Linville, 1985; 1987) than is the norm.

Particular attention in the literature on self-complexity/differentiation (Akrivou, 2009; Johnson, 2000) is on action that includes relational aspects of the leader's experience (for example, in Kegan, 1994; Kegan \& Laskow, 2009; Lahey, 1986). The increase in a leader's degree of differentiation enables both a healthy level of empathizing and simultaneous emotional distance from others' perspectives that is often necessary for decisive action. High self differentiation brings the ability to balance between genuinely empathizing with stakeholders in the system who have conflicting views - arising from divergent goals, and identities— and the ability to retain an independent viewpoint. 
Building on this work, we submit that self-complexity/differentiation is a particularly critical variable for an executive's ability to fully comprehend the cognitive and relational complexity of a given set of circumstances, goals and causes upon which meaning making and sensegiving depend (Mumford \& Strange, 2002; Strange \& Mumford, 2005). Beyond the relational dynamics, highly complex meaning making attends to and balances strategic, technical and behavioral dynamics.

By contrast, a low degree of self-complexity leads executives to narrow definitions of their own interests. In general, low complexity means isolated attention paid to only a few of the variables necessary for understanding the whole system. For example, an executive with low self-complexity might tend to isolate short term financial issues and ignore behavioral dynamics critical to sustainable, outstanding performance. Similarly these executives tend to prefer aligning with only a few groups (for example, the shareholders, or senior management) perceived as dominant; they may cut off others. High complexity in meaning-making, in contrast, is reflected in the way the leader's vision translates into sensegiving, embracing a variety of conflicting issues, while communicating understanding of various stakeholder realities. Low self-complexity may lead to restricting respect to a few powerful stakeholders and attempts to manipulate others.

Proposition 1: The higher an executive's self-complexity, the more likely s/he is to succeed with complex sense making, allowing a complex descriptive abstraction of the system's goals and causes. 
Proposition 1a. The higher an executive's self-complexity, the higher the capacity for translating meaning making into sensegiving. Executives with higher self-complexity can communicate a variety of conflicting issues, while also communicating respect for multiple stakeholders' interests.

Proposition 1b. The higher an executive's self-complexity, the more likely it is that capacity for meaning making and sensegiving translates to ability to mobilize stakeholders to engage in action that embraces complexity.

\section{Operationalizing Complexity / Differentiation}

The operational definition for differentiation or complexity of self most useful to this inquiry is found in the self-concept literature. Particularly Linville's (1985; 1987) work on self-complexity captures well the theoretical frame of the concept of differentiation in constructivist psychology of human development (Akrivou, 2009). Linville's conceptualization of self-complexity focuses on a person's ability to possess numerous specialized identities, or increased cognitive and identity differentiation. Thus, this conceptualization describes a self-concept consisting of multiple "self-aspects" or cognitive categories (Campbell et al, 2003; Linville, 1982). It focuses on complexity of cognition and self-identity. In this literature there are a number of measures to capture self concept differentiation (Campbell, et al., 2003 for review). As most other measures conflate the construct with fragmentation of self they are not deemed appropriate (Akrivou, 2009). 
Based on this operationalization, an executive with high self-complexity has a multi-dimensional self-concept resulting from multiple group memberships, across which differentiated cognitive and behavioral norms apply. The highly complex person therefore displays high tolerance for cognitive and information ambiguity (Linville, 1985).

Self-integration

Perry (1999) views the self-integrated person as able to act in the midst of relativism in a manner that harmonizes with that person's sense of clear personal purpose. Avoiding dogmatic thinking, this individual is open to others' viewpoints (Perry, 1999). Similarly, Loevinger $(1966 ; 1976)$ links self-integration with the ability to tolerate and harmonize unusual amounts of conflict both within the self -mainly involving cognitive and emotional processes- and among others, while avoiding rigidity and dogmatism (for review, Akrivou, 2009).

It is important to note here that while cognitive ability is critical, it is not the central feature and focus of self-integration. Central are post-conventional ethical frameworks, such as Kohlberg's seventh stage of ethical development (Kohlberg \& Ryncarz, 1990) in the post-conventional moral stages of cognitive moral development theory (Kohlberg, 1969). Guiding the choices of such individuals is a unified sense of self who is "part of" a larger system operating with a post-tribal, 'win-win' mentality (Akrivou, 2009). 
Known in later constructive developmental psychology as a "self-transforming mind," self-integration includes the capacity for respecting inter-relatedness and intersubjectivity (Kegan, 1994; Kegan \& Laskow, 2009). The self-integrated person has a process sense of self; in this state of relational integrity, the self is not experienced as a separate, independent (egoic) "I," but rather as a self always in relation (i.e., a trans-egoic self), where relation and the self in relation are themselves experienced as an ongoing fluid process and not as an end state (Akrivou, 2009). Capacity for experiencing the self as process is expressed in both inner experiencing and ongoing action that acknowledges the world as replete with interdependencies. Increasing integration, therefore, allows for increasing resolution of conflict through dialogue and flexibility. Constructs that have been offered to characterize the multi dimensional, post or trans-egoic functioning of such people include 'post-modern self' (Kegan, 1980, 1994) "self-transforming mind" (Kegan \& Laskow, 2009),'strategist' and 'alchemist' stages of development (Torbert et al., 2004), 'third tier development' (Cook-Greuter, 1999), and 'higher level ego development' (Loevinger, 1976; Loevinger, Hy \& Bobbitt, 1998).

Self integration is, however, one of the most conceptually dense (Loevinger, 1976; 1966) constructs both in psychology and constructivist ego development theory. It involves the capacity to harmonize antithetical self-processes. Without self integration, an individual experiences irresolvable tensions (Akrivou, 2009). Self integration includes the balancing of cognition, emotion and behavior (Rogers, 1951; 1961; Loevinger, 1976) with a sense of groundedness in morality imposed by the self and not in accordance with externally imposed moral values. This inner moral compass found in the conceptual definition of self-integration is tied to an ability to critically question one's own behavior, 
and to avoid dogmatism by reflexively questioning one's own convictions in light of the information coming through one's conversations with others. Additionally, this individual harmonizes accountability to society (others common good) and to self; this results in the integrated actor's capacity for effectively transcending the status quo (Loevinger, 1976; Rogers, 1961; Rogers \& Dymond, 1954;) and initiating social and organizational change.

Resulting from these, the meaning making abilities that are the fruit of selfintegration fuel sensegiving, which is synonymous with leadership for the common good (Kegan \& Laskow, 2009), also referred to as the use of socialized power (McClelland, 1975). Thus, building on this work, we argue that a critical predictor of an executive's ability to carry out sensegiving acts that inspire stakeholders is self-integrative meaning making that communicates a socialized power in service to others. The executive with these capacities can effectively push the boundaries of institutionalized inequalities in power relations (Akrivou, 2009; Torbert,1994) to reframe issues and transcend business as usual (Cook Greuter, 1999) to compel strategic transformation (Quinn, 2000).

Congruence between real and ideal self (self-ideal congruence)

In a comprehensive review of the literature, two components of self-integration were identified (Akrivou, 2009). Each has critically distinct effects on integrative meaning making: the degree of congruence between the individual's real and ideal self (Rogers, 
1951; Rogers et al., 1954) and the process sense of self (Akrivou, 2009). Each component has a distinct role that informs sensegiving acts .

Congruence between a person's self-image and his or her ideals engenders both the ability to take values-driven actions and a clear commitment to a specific purpose. This congruence is driven by a rational pursuit of the goal to maintain harmony between one's self and one's value system (Akrivou, 2009). Piaget's The Moral Judgment of the Child (1962) influenced the development of the first component of integration of self. Piaget saw self-ideal congruence as promoting definitive action while also demanding that others act with similar clarity of purpose.

Building on these ideas and relating them to the leadership literature on vision and mental models (Mumford \& Strange, 2002), we suggest that a high degree of congruence between an executive's ideal-real self predicts the ability for meaning making. As an effect of self-complexity, this executive can link a complex descriptive mental model with a future oriented prescriptive mental model.

We suggest that self-ideal congruence equips the executive to translate prescriptive mental models into a compelling vision for future goals of the organization. This process exemplifies "values driven" action. It is very likely that the sensegiving this executive gives to the vision of the system's future will emanate authentically from the fact that there is no discrepancy between real and ideal self aspects. This executive's (leader's) personal vision is in harmony with his/her vision for the entire system and both visions are informed by a similar leadership ethos (Boyatzis \& Akrivou, 2006). Thus, the construct signifies the ability to both create a compelling vision that has a clear ethical framework, and personally "walk the talk." 
Proposition 2: The higher the congruence between an executive's real and ideal self, the more likely it is that the executive has the ability for integrative meaning making, characterized by clear ethical frameworks and definitive sense of direction.

Meaning making translates into sensemaking characterized by the existence of a mental model oriented toward the system's dynamic goals and causes. Thus sensemaking — grounded in clearly articulated ethical values — orients the system toward a clear (comprehensive) and pragmatic path to achieve its goals. The resulting sensegiving effectively reminds stakeholders of ethical commitments. It points to the ongoing need to maintain ethical commitments as a vehicle to meeting collective goals.

Proposition 2a. The higher the congruence between an executive's real and ideal self, the more likely is capacity for sensegiving manifest as a (clear) comprehensible and pragmatic plan of action.

Proposition $2 \mathrm{~b}$. The higher the congruence between an executive's real and ideal selves, the more effective the executive is at engaging stakeholders and maintaining ethical commitments.

\section{The self as process/ the processual self}


The self-as-process, the second component of integration of self, was first conceptualized in Carl Rogers' mature work (1961) and has emerged as a touchstone for the psychology of mature adulthood since the eighties (Loevinger, 1976; Kegan, 1982, 1994). We propose three distinct constructs that are salient in understanding the self as process. One is a person's capacity for situation dependent ways of knowing and relating to others'. This is due to authentic openness to the possibilities that emanate from human relatedness at every moment. The next is a capacity to value others' freedom to express disagreement combined with a deep commitment to inter-dependent ways of knowing and processing information. The third is the capacity to move beyond the search for a "true" self as an independent and self-centered unit and toward a fluid, relational sense of self, which is grounded in mutual, inter-dependent partnerships. It is characterized by increasingly living in a way that makes contributions to self, others and the world as an inseparable interdependent system (Akrivou, 2009). It is a basic theoretical premise of the constructivist psychology of development, from Rogers (1961) and Loevinger (1976), as mentioned earlier in this section, to more recent psychologists (Kegan, 1994; Lahey, 1986; Lahey et al. 1988) that the combination of the first two variables allows integration between the spheres of a person's experience, its mediation through reason and emotion and that this integration is what allows language and action to coordinate inter-subjective action in the social world (Akrivou, 2009). As a result of this integration the benefits of the processual self, namely, relatedness and conversation, engender the capacity for guiding transformation in the system. High integration captures a shift of orientation from a person's pursuit of independent goals and interests to a preference for mutuality and interdependence among actors who are committed to working to achieve their goals 
while advancing the common good. The variable translates into the ability to turn ideas into possibilities (Akrivou, 2009; Cook-Greuter, 1999; Rogers, 1961; Rogers \& Dymond, 1954). An executive who is guided by a processual self has a greater capacity for outstanding common-good leadership which clearly aims in empowering others and the organization (House \& Howell, 1992). This contrasts with self-serving intent (Kets de Vries, 1993; Klein \& House, 1998; Ligon et al., 2008), which may be a darker side of charismatic executive leadership (O’Connor et al., 1995; Yukl, 1999). Because s/he will be able to combine socialized leadership with strategic focus, outstanding performance can ensue. Such leaders also demonstrate confidence in others (McClelland, 1975), thereby empowering others to make and question decisions, communicate effectively, and take action. Others are empowered to act for the collective good (House \& Howell, 1992). Extending this, we argue, therefore, that the capacity for experiencing a process sense of self emphasizes a perspective of interdependence and an orientation toward advancement by way of consensus, rather than by adversarial, or isolated processes. This is a form of integrative sense giving leadership that portends "booting" the organizational system toward adaptive capacities for transformational ongoing change and success (Porras \& Silvers, 1991; Quinn, 2000). For such executives, the future remains open to emergent redirection, which allows for emergent and complex group dynamics (Uhl-Bien et al., 2007).

Proposition 3: The higher the executive's degree of process sense of self, the more likely s/he is to exhibit mutuality thereby allowing the system to evolve organically. 
Executives with a strong process sense of self trust that vision implementation and strategic success depend upon leadership that remains an integral part of the system yet remains open to new possibilities emerging with stakeholders.

Proposition 3a. The higher an executive's degree of process sense of self, the more likely that the resulting sensegiving reflects a "common good" approach to leadership.

Proposition 3b. The higher an executive's degree of process sense of self, the more it translates into executive ability to mobilize stakeholders' transformative action, as opposed to action oriented toward a narrow focus on the success of one's own or group goals.

\section{Operationalizing self-integration}

Self-integration has a dense and abstract definition, a property noted by adult developmental theorists themselves (Loevinger, 1976) that has hindered understanding of it and its use in empirical research. The most well known measures in constructivist ego development literature for the operational definition of self-integration are the Sentence Completion Test (Loevinger et al., 1998), the subject-object interview (Lahey et al., 1988), and the Leader Development Profile (see, Torbert et al., 2004).

A new respondent measure, the Integrative Development Scale (IDS) is being finalized (Akrivou, 2009). It aims to capture the two distinct aspects of self-integration: congruence between a person's real and ideal self and the processual sense of self. 
Higgins has provided an excellent approach to measurement of Self-Ideal Congruence that captures the degree of congruence between a person's ideal and actual self concepts (Higgins, 1987, Higgins et al. 1985; 1986). The first part of the test captures the subject's subjective categorization of Actual-Ideal(ized)-Ought self, while the second requires the subject to define Actual-Ideal(ized)-Ought self systems from the perspectives of significant others. Subsequently, it quantifies self-discrepancies among the Actual-IdealOught selves (Higgins, 1987; Higgins et al. 1985; 1986) using a dictionary based comparison and scoring of synonyms and antonyms. A person with a low or no degree of discrepancy between their actual, ought and idealized selves seamlessly embodies and promote the values they articulate. We posit that such high degrees of integration will also be manifest in the person's ability to form a clear vision of a future idealized state of the system -including and surrounding the self.

Direct measures for experiencing the self as process include a framework on stages of self-transforming mind elicited in the subject-object interview (Kegan, 1994; Lahey et al., 1988) and the upper stages of leadership in the Leader Development Profile (Torbert et al., 2004). Beyond these measures, a number of other qualitative research tools have been identified for use in combination for qualitative research designs to explore newer constructs of "presencing" (Scharmer, 2007) and timely action (Steckler \& Torbert, 2010; Torbert \& Taylor, 2008). These latter simultaneously study and enhance the possibilities of relatedness as rooted in authentic moments of interaction, rather than products of pre-defined cognitive categorizations and instrumental goals. These can be combined with measures capturing the openness to experience construct in psychology, such as defined in the NEO Trait Model (Costa \& McCrae, 1978). 
Measures of absorption, such as those based on Tellegen \& Atkinson (1974) may be close conceptually but problematic to use with executive leaders, as they focus on the trait related to hypnotic susceptibility. Measures of mindfulness (Brown \& Ryan, 2003; Langer, 1989;Langer \& Moldoveanu, 2000) are suitable. The construct of Mindfulness Attention Awareness (Brown \& Ryan, 2003) is the closest conceptually as it captures awareness and attention, both critical to conscious action.

Another indirect measure of the construct may be useful. A process based sense of self presupposes the ability to integrate dialectical opposites that derives from utilizing experience as a source of sensemaking and sensegiving, transforming experience through reflection, conceptualization and experimentation. Stretching beyond the learning mode that is most familiar to oneself, but which often hinders the process of open and interdependent ways of relating and learning with others who have different learning modes, involves both subjective experience and openness to collective experience (Kolb, 1984). Thus we propose the construct of integrative learning as an indirect variable for capturing the self as process. A person's ability to employ systematic variability in learning modes may be measured as adaptive flexibility (Kolb, 1984).

Measurement issues notwithstanding, it appears that the higher levels of self integration offer the first real glimpse of high potential leadership which leads to the following proposition:

Proposition 4. Leadership as manifested in vision and sensegiving that reflect concern for the "common good" emerges from self-integration which then supports organic evolution of a system. 
Figure 2 seeks to integrate the implications of self theory with organizational work on vision and sensegiving.

\author{
Insert figure 2 about here
}

\title{
Discrete versus combined development of self variables
}

We now also look at some downsides to the kind of leader action that may emanate when capacities develop separately, rather than in combination.

Despite the very significant beneficial effects associated with the three variables, an executive who has an isolated focus on one of them alone will either limit or threaten her/his sensegiving capacity and this will lower the likelihood of outstanding leader performance (Mumford et. al., 2008). This is because complexity of self is also accompanied by an increase in relativism (Perry, 1999). A relativist viewpoint understands multiple perspectives as equally legitimate versions of truth. This may result in conventional ethics (Kohlberg, 1969) and or excessively complex processing of information (paralysis by analysis). These can lead to attempts at "political wins" from manipulating stakeholders for the benefit of personal, as opposed to organizational, goals and needs, including decisions and action aimed at the maintenance of organizational social system(s) for the sake of narrowly personal interests and goals. Therefore, when complexity of self is not integrated with self-integration, an increase in complex meaning making will result in relativistic, potentially unethical and/or unfocused leadership. 
Despite the beneficial effects of self-ideal congruence, its untempered increase may be accompanied by rigidity. The congruence between ideal and real self in conventional self-integration literature supposes meaning making is tied to the notion of having arrived at one's destination, i.e., a goal based view of self (Akrivou, 2009). The isolated effects of this variable in the executive self-system can extend to a focus on overly rational alignment and insistence on "sticking to the plans agreed." This can lead to narcissistic patterns of leader behavior in contrast with the potential benefit of allowing organic evolution of interdependence guide what needs to be done to ensure organizational adaptiveness. This goal based understanding of leadership can, in turn, result in more rigidity among system actors and stakeholder groups that are far from having reached alignment. This would, in turn, hinder actual transformation of the stakeholders and the social tissue of the organization in general, as it would be difficult to assure balanced coexistence between strategic action and organic adaptive capacities.

Use of the processual self engenders openness to creative experience and fluidity in interactions with others. Nevertheless, especially in initial phases of strategic transformation, it could be argued that overreliance on the processual self can both threaten the executive's ability to take action and dissipate strategic focus.

Lack of a clear direction can hinder other actors. It may reduce an executive's sense of responsibility for the stakeholders. Potentially, overreliance on the processual self risks causing stakeholders to mistrust the leader's capacities and to doubt whether there is a convincing vision and strategy for the future (Ligon et al., 2008; Mumford et al., 2008). 


\section{Dynamic Evolution Toward System Transformation: A Process Model}

Thus far, we have looked at the impact of intrapersonal self-system capacities of differentiation/complexity and integration as a static model. We may well ask, pragmatically, what facilitates an increase in stakeholder engagement in the executive's acts of sensegiving over time (Maitlis \& Lawrence, 2007)? To address this inquiry, we draw from a view of organizations as complex interactive systems (Marion \& Uhl Bien, 2001; Uhl Bien et al., 2007).

The distinction between leaders and leadership in the organization (Uhl Bien et al., 2007) is a key feature of complexity leadership. The distinction is based on the assumption that leadership is socially constructed (Cillier, 1998; Dooley, 1996; Hosking, 1998). Leadership has been defined as "an emergent inter active dynamic that is itself productive of adaptive outcomes" (Uhl Bien et al., 2007). Complexity leadership scholars argue that system performance outcomes are produced (Uhl Bien et al., 2007) by the nexus between individual leaders and collective expression of leadership.

In Proposition 4 we proposed that a leader's acts of leadership predominately consist of two variables, visioning and leading for the common good - by activating interactive dynamics of leadership in the organization. Accordingly, we posit that stakeholders' engagement as co-participants of leadership in the dynamics of meeting visionary goals is also itself a non linear outcome of the executive/leader's intentional action as a catalyst. This is because despite the linear effects of their sensegiving charisma "leaders.....owe their existence to interactive dynamics" and are aware that "...success is that the nature of interaction is not predetermined or constrained by 
leadership (rules, agendas, powerful leadership vision, etc) fiat, ....but,...depends on emergent distributed intelligence," (Marion \& Uhl Bien: 2001, pp. 398). Thus, the effects of the leader catalyst role in bringing about system engagement may be predicted as described by Marion \& Uhl Bien:

“(Catalysts) speed up a process which could conceivably occur without the catalyst, but that would take forever to do so. A catalyst can also make things happen that would not happen otherwise, (2001: 398)."

As to the process dynamics of the catalyst role, we share with scholars of complexity leadership assumptions about non linear dynamics of transformation. Two processes inherent in inter-dependent complex system are especially noteworthy: the diffusion and sharing of internal control (Marion, \& Uhl Bien, 2001) and the diffusion and sharing of inter-agent accountability (Marion \& Uhl Bien, 2001; Schneider \& Somers, 2006).

By creating and maintaining enabling conditions the executive catalyst's sensegiving role ensures entanglement of stakeholders (Kontopoulos, 1993) in interdependency and inter-accountability throughout levels of organization. Entanglement facilitates sharing of leadership among formal and informal constituents and actors. Thus, meaning making by an executive/leader remains a central aspect of the organizational capacity for transformation.

Figure 3 offers a process model linking executive meaning making, sensegiving and strategic action over time. We acknowledge that much work is required to explicate this bridge further, but that lies beyond the purview of our focus here on catalytic prerequisites. Therefore in figure 3 , the term "system engagement" refers also to the 
effects of entanglement among levels in the organization. Our understanding of engagement, schematically summarized in figure 3, refers to actor sensemaking processes produced "locally" in a direct response to actors' engagement with the executive vision. Thus it involves engagement processes non mediated by the managerial core of the organization. We propose that an executive's (leader's) vision of shared internal control motivates the constituents to common purpose and instills a sense of accountability. Second, we propose that the socialized executive's/ leader's sensegiving aims at transcendence of individual's over focus on self-interest and a particular's group's excessive focus on protecting or defending its perceived interests.

\section{INSERT FIGURE 3 ABOUT HERE}

Proposition 5: The higher the levels of all three variables of self-complexity, self-ideal congruence and the process sense of self in the executive self-system, the more likely s/he is to catalyze stakeholder engagement, predictive of outstanding performance.

We link the increase in the density of the network of highly inter-dependent agents - a key capacity of complex systems (Uhl-Bien et al, 2007) - to the self-system capacities. Unless and until a critical mass of (other) leaders emerges to participate in system transformation, the executive catalyst has not been successful. To help situate our contribution in this process model, we suggest that our work may be extended beyond an understanding of the catalytic phase, so that it may bridge to our understanding of change based on the literatures of complexity leadership (Marion \& Uhl Bien, 2001; Uhl Bien et 
al., 2007) and of sensemaking/sensegiving (Balogun 2003; Bartunek \& colleagues, 1999; Corley \& Gioia, 2004; Dunford \& Jones 2000; Dutton et al., 2002; Heller, 1998; Kuhn, 2008; Maitlis, 2005; McNulty \& Pettigrew, 1999; Snell, 2002; Weick, 1993, 1995). Cumulative impacts occur in key intertwined relational realms - that is, within the executive self, with the executive's peers and with and among other key stakeholdersallowing a relational (Kuhn, 2008) and shared exercise of and capacity for leadership. Thus a progressively larger circle of stakeholders engages in the transformative agenda. In the process of leadership emergence, the catalytic executive is both catalyst and enzyme who becomes part of a shared process.

Proposition 6: The greater the capacity for aligned sensemaking and stakeholder consensus (involving self, peer executives, and stakeholders), the more likely it is that there will be an increase in collective capacity for action predictive of outstanding performance.

\section{DISCUSSION}

Leadership research has achieved significant progress in recent years by explaining crucial elements and processes for organizational adaptability that lead to sustaining success amid complex demands. Crucial has been shedding light on the origins of vision as rooted in executive meaning making (Mumford et. al., 2008; Strange \& Mumford, 2005), Moreover, research links visioning capacity to processes that predict the enabling of reflexive capacities of complex adaptive systems (Uhl-Bien et al., 2007). 
This article proposed a process model of outstanding leadership linking these two lines of research and highlighting antecedents that are rooted in individual ego structure We discussed a progressive process of executive leadership that occurs at three levels of analysis:

First is an intra-personal level of ego structure in which abilities for complex and integrative meaning making are seen as core.

Second involves the executive ability for vision and sensegiving which results from utilization of complex and integrative sensemaking. At this level we drew from the related literature and theory on vision and mental models (Mumford et al., 2008), as well as on informal acts of direct sensegiving in interaction with stakeholders (Gioia \& Chittipeddi, 1991). We hypothesized linear effects between the executive's vision and sensegiving and engagement of the surrounding social system. We also predicted initial effects on leader performance based on the executive's individual capacities.

Third is diffusion of the executives' influence in the organization that engages complexity leadership processes among stakeholders. At this level we hypothesized non linear interactions, involving the entire organizational system of actors. These interactions result in the emergence of a complex adaptive system (CAS) which then affects leader and organizational performance.

\section{Implications for Theory and Research}

Our theoretical model is informative, but not complete. Realizing that an exclusively external focus offers but a partial view of reality (Bateson 1972, Harman 
1996), we consider that leadership studies might continue to move beyond research that bifurcates phenomena that can be mechanically measured from those that cannot. Therefore, in addition to studying explicit behaviors and visible social structures related to leadership, we also want to integrate assessment of interior internal phenomena, including tacit beliefs and behavioral structures that influence personal, interpersonal, and multipersonal research (Bradbury and Lichtenstein, 2000). We must, however, recognize the not insignificant obstacle that the subjective and qualitative nature of so many of the measures of developmental psychology presents.

We suggest a research program that includes focus on both the external and interior nature of organizational phenomena. A framework for this may be built upon three interdependent research-practice categories: third-person, second-person, and firstperson research practice (Chandler \& Torbert, 2003). Third-person research is conducted within the community of scholars with a keen eye to establishing validity. Second-person or interpersonal research-practice actively engages others as co-researchers. This would mean examining the relational-interactive aspects of leadership with the leaders themselves. First-person or personal research-practice is conducted alone by the individual leaders themselves.

\section{Hypothesis testing ("third person research")}

A primary research direction from this paper should naturally aim to empirically test the proposed theoretical model (Figure 3). Research that integrates an understanding of multi-level influences across the variables in the intrapersonal, group and 
organizational levels would be key. This requires a research team to bring together backgrounds in different aspects of the self-system variables; a team could ideally sum their separate work to gain a more comprehensive understanding of leadership. The design would include research on leader vision and mental models, sensemaking and leadership complexity. Therefore further empirical work requires a multi-method, multilevel research design to bridge multiple levels of analysis.

In our model we emphasized a complexity leadership approach, with an emphasis on the interactive non linear dynamics producing distributed intelligence and engagement as an effect of the leader-catalyst role. However, to capture early process dynamics of leader sensegiving that may still entail linear relationship between variables, literature on CEO/executive leadership personal type effects across hierarchical echelons appear quite relevant, e.g., follower and stakeholder group variables, and levels of analysis based on cross-level (Rousseau, 1985) and multi-level research on leadership (Dansereau et al., 1984; Klein et al., 1994). Multi-level leadership research designs are well exemplified in the work of Waldman and Yammarino (1999). However, these need to be integrated into a complexity leadership research design.

To help test our core assumption of the process represented by Figure 3, a multilevel design needs to capture both individual executive leader effects — close and distant, involving the top echelon and various managerial levels_ - and collective non linear dynamic leadership processes.

In addition, we see the need to look at how different leadership efforts (socialized vs. personalized) are causally related to different degrees of self complexity/integration. 
Another direction would include exploration of processes of leadership emergence under conditions of socialized leadership.

\section{Relational impact of leadership ("second person research")}

We see leader emergence as an interactive process, one that is reciprocalhappening in the "relational space between" (Bradbury and Lichtenstein, 2000), executive catalyst and organization. Further research should be done to understand how this relationship enables leader emergence. Research that pinpoints spaces in the formal and informal organization that yield leader emergence is needed.

A second issue is to more closely examine multi-level influences and effects on

emergence (Mumford et al., 2008). With regard to other individual, group, organizational and contextual variables, it would be useful to ascertain which are parsimoniously adequate to co-activate the leader emergence suggested in our model. Three questions are important here: (1) What is the critical mass of leaders necessary to activate broad scale uptake of a change \& transformation dynamic? (2) When does balance arise between managerial and informal leadership? (3), When does "voice" emerge in lower parts of the organization?

\section{Developing individual capacity (first person research).}


Our first-person action research/practice would address the ability of the (potential) executive to foster an inquiring approach to her or his own life and to act choicefully and with awareness as a means of producing desired effects in the outside world. This involves analysis of the effect of executive self system variables, with regard to development of leader vision and mental models (Mumford et al., 2008).

Another important area for research would investigate skills of motivating others especially in highly politicized contexts; this would increase understanding of techniques that promote success.

Finally, a useful research direction would examine the effects of life narrative in a leaders' self-development (Ligon et al., 2008). Ligon, Hunter and Mumford showed (2008) that attention should be paid to working with developmental experiences in particular. They propose that while many individuals have rich experiences, leaders especially can benefit from reflection on their experience as a tool to generate the mental models (Mumford et al., 2008) necessary for outstanding leadership. We see exciting possibilities to extend this work by hypothesis testing and / or qualitative research (Bryman et al., 1988) to explore if outstanding leadership results from earlier life events. We'd also investigate if outstanding leaders' subsequent reflection and meta-narratives have multiplying effects that enrich self complexity and integration over time. If results of this research bear fruit this means a whole new arena of reflective practices and leadership development might be studied.

\section{Developing executive catalysts}


The model and core thesis should inform practice and practice oriented research on leadership as a process (Uhl-Bien et al., 2007). We suggest that business promotion /appointment decisions can be based on the executive self system variables of complexity and integration to predict outstanding leader performance. Implications on appointing individuals with more complexity should therefore inform practice. Often, appointment decisions for executive roles are made based on evidence of managerial performance in functional roles. This results in the skills exhibited reflecting egoic/personalized and highly rationalized leadership. Particularly insightful, therefore, would be for practitioners and scholars to work together on the question of what type of decision making might better advance those individuals more capable of leadership for the common good.

Two directions are promising: new research on the negative effects of overemphasizing self-esteem (e.g., Ryan \& Brown's, 2003) and the requirement among potential leaders to take time to reflect upon and learn from personal experiences (Mumford et al, 2000).

Ryan and Brown's work calls into question the preoccupation with the "self-asobject" (McAdams, 1990), that leads to self-enhancement behaviors contingent on external circumstances (e.g., others regard), that in turn leads to self-regulation processes seen linked to egoic and personalized leadership. At the risk of overstatement, we suggest that the entire leader development paradigm, so prevalent in the last decade(s) in business schools around the world, must be critiqued. The time may have come to learn from enduring Buddhist psychology whose notions of a more fluid self are empirically associated with "a healthier and more vital living" (Ryan \& Brown, 2003, pp. 71). The 
need for expression of a potential leader's multiple self-identities may also call for conversation based experiential learning (Kolb and Kolb, 2005) suited to selfdevelopment —one in which peer-learners, perhaps across organizations, can share their own experiences in dialogue with others.

In addition to identifying predictors of executive leadership performance in an environment of complex demands of the knowledge era we have begun to formulate requirements for developing these capacities. If, as we argue, complexity of self and related capacity for increased congruence and the capacity for a processual self best equip executives to lead successfully amid complex demands, then methods for developing these capacities are critical, because these are not commonplace capacities. Empirical researchers report that they "naturally occur" at a rate of 1/100 (Kegan, 1994; Rooke \& Torbert, 2005). Thus, an organization's conscious and systematic effort to develop them is both necessary and timely (Boyatzis et al. 2006). An important question, therefore, is how learnable these capacities are. Besides, the development of deep structure individual capacities requires self-direction and deep learning by the individual (Kolb \& al. 1968; Kolb \& Boyatzis, 1970). If we assume that these capacities are not easily learned, then it is important to identify responsibly which individuals could emerge as potential leadercatalysts. Research on the examination of biographies for prediction of leader emergence can be informative. Accordingly, managers considered for executive roles can be asked to narrate their biographies, which then can be reviewed for markers of complexity/differentiation and integration of self in the meaning making of their own life stories. 
In this regard, it is worth reviewing results of work that looks at the relationships between adult high end development and leadership. Bartone's et al. 2007 study suggests that substantial adult psychosocial development is achievable. This finding underscores the importance of understanding which capacities executives should and can develop. Their work reports on the results of the largest longitudinal study to date which measured psychosocial development using Lahey/Kegan's subject object interview. The researchers tracked students at West Point over four years. $47 \%$ of the 21 students tracked showed “substantial psychosocial development"-equivalent to development of a full order of consciousness (roughly equivalent to two stages of ego development in Loevinger's model or two action logics in Torbert's model, suggestive of a high score using the measures discussed above).

In the Bartone et al. 2007 study, as in most that deal with adult high end development abilities (cf. also Wilber et al, 1986), sample sizes are necessarily small. We believe it is important to contest the assumption that small samples size is always an empirical limitation. In some circumstances small sample size may not be an empirical limitation, e.g., if a very large percentage of the variance is accounted for at a high level of statistical significance, as reported in Rooke \& Torbert's (2005) research on the success of CEOs in 10 organizations in generating organizational transformation (variance is $59 \%$ and significance is 0.1 ). Indeed, the combination of "small sample size"/"large proportion of variance explained"/".01 significance" may indeed be the most powerful possible. Put differently, studies that integrate quantitative, qualitative and action research so as to allow consistent demonstration of know how or actionability (Bradbury, 2007, Bradbury-Huang, 2010) will tend to be of this kind. 
Moreover the action research/learning paradigm tends toward an integrative approach to change (Reason \& Bradbury, 2008), suggesting equal emphasis for individual change agents on inner arcs of attention (e.g., what individuals are capable of noting with regard to their own cognitive activity and proto-leadership experiences) and outer arcs of attention (e.g., how much they are aware of how others respond to them). The shifts in self-complexity and integration we are writing about surely need to be tested in action through cycles of inquiry, so that the inner cognitive complexity is linked to developing skills with practice.

\section{Limitations}

Two focal limitations of this paper must be noted. Although an effort was made to do a thorough analysis of the effects of the variables and the processes, it has not been possible to provide an in-depth analysis of specific challenges and problems at each level of analysis. Further theoretical work needs to address two key issues that deal with interactions and influence processes among executives, stakeholders and shareholders.

First, the theorized link between (complex and integrative) executive meaning making and the communication of an engaging vision may be examined to uncover specifically how these variables address problems of stakeholder agency related to the viability and effectiveness of the executive vision. In the corporate governance literature stakeholder agency theory's (Hill, \& Jones, 1992) attention to power differentials across stakeholder groups - based on agency theory's (Jensen and Meckling, 1976) formulation of core problems in the relationship between executive managers and shareholders - 
require attention; both theories acknowledge the centrality of executive - agent for resolving stakeholder power dynamics. In the case of our model of catalyst leadership these theories can inform a more detailed understanding of the complex interaction between the catalyst vision and sensegiving action for the diffusion of power and effects on intra-organizational power in the social organization. How specifically theorized catalyst leadership allows the social organization to "author itself," while maintaining capacity for acting responsibly as stakeholder engaged in the process of co-creating sustainable organizational performance needs to be addressed systematically. A related further exploration is how these processes influence the evolution of the executive's vision through time, and how the organization responds in such evolutions in terms of complexity leadership processes, as we proposed.

A second issue that requires attention is the role of leaders in cultivating and spreading leadership in the system. A theoretical assumption of this paper is that greater self complexity and integration yields a shift in the catalytic executive from egocentric/unilateral to interdependent/enabling type of leadership. Although we propose that that change will facilitate the progressive system development from the engagement to the consensus phases, we have remained focused on the role and effects of the executive leader variables in the system. Although we propose the emergence of a number of formal and informal leaders with capacities for complex and integrative meaning making, this paper did not go into detail. Thus, an actor based analysis of this process will offer a useful contribution, as it may help understand dynamic points in the process of emergence where local stakeholder and management actor sensemaking may have increased impact. 
The limitations speak to the requirements of further research to help understand micro dynamics of sensemaking and sensegiving in organizational change (Gioia \& Chittipeddi, 1991). We believe that there is a potential to utilize this line of research to support further progress theory on complexity leadership, in line with the call of scholars for additional research on processes of the complex adaptive systems (Uhl Bien et al., 2007).

\section{Conclusion}

This paper suggests that we can identify the individual level capacities that best equip executives in an environment of complex demands to be catalysts for transformation. This set of capacities had not been adequately explicated to date. We suggest that particular psychological antecedents warrant attention: complexity of self, differentiation of self, and the dynamics of self-integration. Together these engender a process whereby the leader, having reached a level of cognitive autonomy, becomes simultaneously capable of complex and integrative understandings of the world. These understandings go beyond black and white thinking. Importantly, the combination of the two components of self-integration proposed enables a capacity for interdependence with stakeholders, and ethical, purposeful action as an outcome of congruence between the ideal and real value systems of the executive. In turn, this capacity is experienced as motivational for stakeholders, with the result that the post-autonomous executive ("I") manages to simultaneously guide and co-create a collective ("we") identity - by balancing authority and mutuality. This new identity supports a shared vision as well as 
coordinating collective action. Our use of the catalyst metaphor allows for extending our efforts to the larger domain of organizational change, through the perspective on sensemaking - sensegiving. Thus we consider the executive as a catalyst who engages in sense giving for stakeholders so that their subsequent sensemaking of strategy and vision may support the collective capacity for action.

This sort of executive impact we propose entails a complex and committed strategy and language that are a product both of meaning making and of authentically relating and communicating. Higher capacity for meaning making is linked to the understanding that strategy is necessarily tied to a commitment to the task of leadership as collective shared responsibility. Sharing responsibility and leadership cannot guarantee transformation will be successful. It is a cumbersome and emergent process. It requires the individual executive ability to catalyze this developmental task, effectively build interdependence among and between stakeholders. This is why the continuing executive ability to catalyze this process is itself a predictor of its success. Thus the proposed model does not explain transformation as a result of intentionally "playing" to dynamics of personal and social identification so to succeed at having change accepted (Gardner \& Avolio, 1998). In our model, the conditions for catalyzing transformation are the levels of executive self-complexity and self-integration.

Certainly more research is needed. Future directions for this research have also been highlighted. This research is important for increasing scholarly understanding. It is also important for bringing attention to how practitioner capacity might be enhanced. We hope that this work will find new ways to transform understanding and enhance practice 
Executive Catalysts: Predicting Sustainable Organizational Performance Amid Complex Demands

at a time of shift from the industrial to a more complex but potentially sustainable, post industrial era for organizations. 


\section{References}

Akrivou, K. (2009), Differentiation and Integration in Adult Development: The Role of Self-Complexity and Integrative Learning in Self-Integration, Monograph based on Ph.D dissertation², Munich: VDM Verlag (ISBN 978-3-639-15116-9).

Albert, Stuart (1995). Toward a theory of timing: An archival study of timing decisions in the Persian Gulf War. Research in Organizational Behavior, 17: 1-70. Greenwich: CT: JAI Press.

Baker, A., Jensen, P., and Kolb D. (2002). Conversational Learning: An Experiential Approach to Knowledge Creation. Westport, CT \& London: Quorum Books.

Baker, A., Jensen, P., and Kolb D. (2005). Conversation as Experiential Learning, Management Learning, 36, 4, 1350-76.

Balogun, J. (2003). From blaming the middle to harnessing its potential: Creating change intermediaries. British Journal of Management, 14: 69-83.

\footnotetext{
${ }^{2}$ Original Reference of Ph.D Thesis upon which this monograph is based is:

Akrivou, K., 2008, Differentiation and Integration in Adult Development: the role of self-complexity and integrative learning in self-integration. Case Western Reserve University, Department of Organizational Behaviour: Cleveland, OH, U.S.A.
} 
Balogun, J., \& Johnson, G. (2004). Organizational restructuring and middle manager sensemaking. Academy of Management Journal, 47: 523-549.

Bartone, P. T., Snook S. , George B. Forsythe, Philip Lewis, Richard C. Bullis. (2007). Psychosocial development and leader performance of military officer cadets. The Leadership Quarterly, 18490 - 504.

Bartunek, J. M., Gordon, J. R., Weathersby, R. P.(1983). Developing "Complicated" Understanding in Administrators, Academy of Management Review, 8, 273-285.

Bartunek, J., Krim, R., Necochea, R., \& Humphries, M. (1999). Sensemaking, sensegiving, and leadership in strategic organizational development. In J. Wagner (Ed.), Advances in qualitative organizational research, vol. 2: 37-71. Greenwich, CT: JAI Press.

Bass B.M. (1985), Leadership and performance beyond expectations. New York: Free Press

Bass, B. M. (1990). Bass and Stogdill's Handbook of Leadership. New York: Free Press.

Bateson, G. (1972). Steps to an ecology of mind: Collected essays in anthropology, psychiatry, evolution and epistemology. Chandler Publishing: San Frascisco, CA.

Boyatzis, R. E., \& Akrivou, K. (2006). The Ideal Self as a driver of intentional change. Journal of Management Development, 25(7), 624-642. 
Boyatzis, Smith M. \& Blaize, N. (2006). Developing Sustainable Leaders through Coaching and Compassion, Academy of Management Learning and Education, $5(1), 8-24$.

Bradbury, H. \& Lichtenstein, B. (2000). The space between: Operationalizing relationality in organizational research. Organization Science. November. 11 (5): $551-564$.

Bradbury, H. (2007). Quality, Consequence and 'Actionability': What action researchers offer from the tradition of Pragmatism. In Mohrman et al. (eds) 2007. Handbook of Collaborative Management Research. Sage Publications.

Bradbury-Huang, H. (2010). What is Good Action Research? Action Research Journal. 8 (1) $1-11$.

Brown, K.W., \& Ryan, R. M. (2003), The Benefits of Being Present: Mindfulness and Its Role in Psychological Well Being, Journal of Personality and Social Psychology, $84(4), 822-848$.

Brown, M.E. \& Trevino L.K. (2006). Ethical leadership: A review and future directions, The Leadership Quarterly, 17, 595-616. 
Bryman, A., Bresnen, M., Beardsworth, A. and Keil, T. (1988). Qualitative research and the study of leadership. Human Relations, 1988, 41 13-30.

Campbell, J. D., Assanand, S., \& Di Paula, A. (2003). The Structure of the Self-Concept and Its Relation to Psychological Adjustment. Journal of Personality, 7(1), 115140.

Chandler, D.E., \& Torbert, W.R. (2003). Transforming inquiry and action: Interweaving 27 flavors of action research. Action Research. Volume 1(2): 133-152.

Chatterjee, A., Hambrick, D.C., (2007). It's All about Me: Narcissistic Chief Executive Officers and their effects on Company Strategy and Performance, Administrative Science Quarterly, 52, 351-386.

Cilliers, P. (1998). Complexity and post-modernism: Understanding Complex systems. London: Routledge.

Ciulla (1995). Leadership Ethics: Mapping the Territory. Business Ethics Quarterly, 5(1):5-28.

Clegg, S.R., Kornberger, M., Carter, C., Rhodes, C. (2006). For Management? Management Learning, 37 (1), 7-27. 
Cook-Greuter, S. R. (1999), Post-Autonomous ego development; A study on its nature and its measurement, Graduate School of Education, Harvard University.

Corley, K. G., \& Gioia, D. A. (2004). Identity ambiguity and change in the wake of a corporate spin-off. Administrative Science Quarterly, 49: 173-208. Deetz, S. 2003. Reclaiming the legacy of the linguistic turn. Organization. 10 (3) 421.

Costa, P. T., Jr., \& McCrae, R.R. (1978). Objective Personality Assessment. In M. Storandt, I.C. Siegler, \& M.F. Eliase (Eds.), The clinical psychology of aging. New York; Plenum Press.

Dansereau F., Yammarino, F.J., \& Markham, S.E (1995), Leadership: the Multiple level approaches. Leadership Quarterly, 6, 97-109.

Doh, J.P. \& Stumpf, S.A. (2005). Toward a Framework of Responsible Leadership and Governance. In J.P. Doh \& S.A. Stumpf (Eds.), Handbook of Responsible Leadership and Governance in Global Business. Cheltenham: Edward Elgar, p. 3-18. 
Dooley, K.J. (1996, 10.26.96). Complex Adaptive Systems: A nominal definition, from http://www.eas.asu.edu/kdooley/casopdef.html

Dunford, R., \& Jones, D. (2000). Narrative in strategic change. Human Relations, 53: $1207-1226$.

Dutton, J. E., Ashford, S. J., Lawrence, K. A., \& Miner- Rubino, K. (2002). Red light, green light: Making sense of the organizational context for issue selling. Organization Science, 13: 355-372

Emmons, R. (1987). Narcissism: Theory and Measurement, Journal of Personality and Social Psychology, 52:11-17.

Fingarette H. (1963). The self in transformation. New York: Harper and Row

Gadamer, H-G. (1965). Truth and Method. New York: Crossroad.

Gioia, D. A., \& Chittipeddi, K. (1991). Sensemaking and sensegiving in strategic change initiation. Strategic Management Journal, 12: 433-448.

Harman, W. A. (1996). The shortcomings of western Science. Qualitative Inquiry (Special Issue on Qulity in Human Inquiry). Y. Lincoln, P. Reason, eds. 2 (1) 30-38 
Heller, F. A. (1998). Influence at work: A 25-year program of research. Human Relations, 51: 1425-1456.

Higgins, E. T (1987). Self-Discrepancy: a theory relating self and affect. Psychological Review, 94(3), 319-340.

Higgins, E. T, Klein, R., \& Strauman, T. (1985). Self-Concept Discrepancy Theory: A psychological model for distinguishing among different aspects of depression and anxiety. Social Cognition, 3(1), 51-77.

Higgins, E.T., Bond, R. N., Klein, R, \& Strauman, T. (1986). Self-discrepancies and emotional vulnerability: how magnitude, accessibility and type of discrepancy influence affect. Journal of Personality and Social Psychology, 51, 5-15.

Hill, C. W.L., \& Jones, T.M. (1992). Stakeholder-Agency Theory, Journal of Management Studies, 29 (2), 131-154.

Hosking, D.M. (1988). Organizing, Leadership and skilful process. Journal of Management Studies, 25, 147-166.

House, R. J., \& Howell, J. M. (1992). Personality and Charismatic Leadership. Leadership Quarterly,3, 81-108. 
Jensen, M.C. \& Meckling, W. H. (1976). Theory of the firm: managerial behavior, agency costs, and ownership structure. Journal of financial economics, 3, 305-60.

Johnson, V. A. (2000). The concept of Differentiation as a contribution to the psychology of maturity. Harvard University.

Kegan, R. (1982). The evolving self. Cambridge: Harvard University Press.

Kegan, R. (1994). In Over our Heads: The Mental Demands of Modern Life. Cambridge, MA, London, UK: Harvard University Press.

Kegan, R., Laskow, L.L. (2009) Immunity to Change. Harvard Business School: Boston, MA.

Kets De Vries, M.F.R. (1993). Leaders, fools and imposter: Essays on the psychology of leadership. San Francisco: Jossey Bass.

Klein K.J., Dansereau, F,\& Hall, R.J. (1994), Levels issues in theory development, data collection and analysis. Academy of Management Review, 19, 195-229.

Klein, K.J., \& House, R.J. (1998). Further thoughts on fire: Charismatic leadership and levels of analysis. In F. Dansereau \& F. J. Jammarino (Eds.), Leadership: The multiple level approaches, vol.2: 42-52, Stanford, CT: JAI Press. 
Kohlberg, L. (1969). Stage and Sequence: The Cognitive-developmental approach to socialization. In D. A. Goslin (Ed.), Handbook of socialization theory and research. Skokie, Ill: Rand McNally.

Kohlberg, L., and Ryncarz R.A. (1990). Beyond Justice Reasoning: Moral Development and Consideration of a Seventh Stages. In, Higher Stages of Moral Development, Alexander, N., and Langer, E.J. (Eds.), New York: Oxford University Press.

Kolb, D. A. (1984). Experiential Learning. New Jersey: Prentice Hall, Inc.

Kolb, D. A., \& Boyatzis, R. E. (1970). Goal-setting and self-directed behavior change. Human Relations, 23(5), 439-457

Kolb, D. A., Winter, S. K., \& Berlew, D. E. (1968). Self-directed change: Two studies. Journal of Applied Behavioral Science, 6(3), 453-471.

Kontopoulos, K.M. (1993). The logics of social structure. Cambridge: Cambridge University Press.

Kuhn, T. (2008). A Communicative Theory of the Firm: Developing an Alternative Perspective on Intra-organizational Power and Stakeholder Relationships. Organization Studies. 29 (8/9): 1227. 
Lahey, L. L. (1986). Males' and females' construction of conflict in work and love. Harvard University.

Lahey, L., Souvaine, E., Kegan, R., Goodman, R., Felix, S. (1988). A guide to the subject-object interview: its administration and interpretation. Harvard Graduate School of Education, Cambridge: Laboratory of Human Development.

Langer, E.J. (1989). Mindfulness, Reading, MA: Addison Wesley.

Langer, E.J., \& Moldoveanu, M. (2000). The Construct of Mindfulness. Journal of Social Issues, 56, 1-9.

Ligon, G.S., Hunter, S.T., Mumford, M.D.(2008). Development of Outstanding Leadership. A life Narrative Approach. The Leadership Quarterly, 19,312-334

Linville, P. W. (1982). The complexity-extremity effect and age-based stereotyping. Journal of Personality and Social Psychology, 42(2), 193-211.

Linville, P. W. (1985). Self-complexity and affective extremity: Don't put all of your eggs in one cognitive basket. Social Cognition, 3, 94-120.

Linville, P. W. (1987). Self-complexity as a cognitive buffer against stress-related illness and depression. Journal of Personality and Social Psychology, 52(4), 663-676. 
Loevinger, J. (1966). The meaning and measurement of ego development. American Psychologist, 21, 195-206.

Loevinger, J. (1976). Ego Development: Conceptions and theories. San Francisco, CA: Jossey Bass, Inc.

Loevinger, J., Hy, L., Bobbitt, K.(1998). Revision of the Scoring Manual. In J. Loevinger (Ed.), Technical Foundations for measuring ego development: The Washington University Sentence Completion Test, Mahwah, NJ: Lawrence Erlbaum.

Maak, T. (2007). Responsible Leadership, Stakeholder Engagement, and the Emergence of Social Capital, Journal of Business Ethics, 74, 329-343.

Maak,T, \& Pless, N. (2006). Responsible Leadership: A Relational Approach. In T. Maak \& Pless (Eds.), Responsible Leadership. New York: routledge: pp.33-54

Maitlis, S. (2005). The social processes of organizational sensemaking. Academy of Management Journal, 48: 21-49.

Maitlis, S. \& Lawrence., T. B. (2007). Triggers and enablers of sensegiving in organizations. Academy of Management Journal. 50(1), 57-84

Marion, R., \& Uhl-Bien, M. (2001). Leadership in Complex Organizations. The Leadership Quarterly, 12, 389-418. 
Executive Catalysts: Predicting Sustainable Organizational Performance Amid Complex Demands

McAdams, D.P. (1990). The person: An Introduction to Personality Psychology. New York: Harcourt Brace.

McCauley, C.D., Drath, W. H., Palus, C.J., O'Connor P.M.G., Baker, B. A. (2006). The use of constructive-developmental theory to advance the understanding of leadership, The Leadership Quarterly, 17, 634-653.

McClelland, D.C. (1975). Power: The Inner Experience. New York, Irvington.

McNulty, T., \& Pettigrew, A. M. (1999). Strategists on the board. Organization Studies, 20: $47-74$.

Morgan, G. 1986. Images of Organization. Newbury Park: Sage Publications.

Mumford, M.D. (2006). Pathways to outstanding leadership: A comparative analysis of charismatic, ideological and pragmatic leaders. Mahwah, NJ: Erlbaum

Mumford, M.D., Antes, A.L., Caughron, J.J., Friedrich, T.L. (2008). Charismatic, ideological and pragmatic leadership: multi-level influences on emergence and performance, The Leadership Quarterly, 19, 144-160. 
Mumford, M.D., \& Strange, J.M. (2002). Vision and mental models: The case of charismatic and ideological leadership. In B. J. Avolio \&F.J. Yammarino (Eds.), charismatic and transformational leadership: The road Ahead (pp. 109-142). Oxford, UK: Elsevier.

Mumford, M.D., Zaccaro, S.J., Harding, F.D., Jacobs, T.O., Fleischman, E.A. (2000), Leadership Skills for a Changing World: Solving Complex Social Problems, Leadership Quarterly, 11 (1), 11-35.

O'Connor, J.A., Mumford, M.D.,Clifton, T.C.,Gessner, T.E., \& Connely, M.S.(1995), Charismatic Leadership and destructiveness: A historiometric study. Leadership Quarterly, 6, 529-555.

Paine, L. S. (2003). Value shift: Why companies must merge social and financial imperatives to achieve superior performance. New York: McGraw Hill.

Perry, W. G. (1999). Ethical \& Intellectual Development in the College Years. San Francisco, CA: Jossey Bass, copyright J. Wiley \& Sons.

Piaget, J. (1962). The moral judgement of the Child. New York, N.Y.: Collier Books. 
Porras, J. I., \& Silvers, R. C. (1991). Organizational development and transformation. Annual Review of Psychology, 42, 51-7.

Quinn, R. (2000). Change the World. San Francisco: Jossey Bass.

Raskin, R., and Terry, H. (1988) A principal-components analysis of the narcissistic personality inventory and further evidence of its construct validity. Journal of Personality and Social Psychology, 54, 890-902

Reason, P. and H. Bradbury, Eds. (2008). The Handbook of Action Research. U.S./U.K.: Sage Publications.

Riceour, P. (1976). Interpretation Theory: Discourse and the Surplus of Meaning. Fort Worth: Texas Christian Press.

Rogers, C. R. (1961). On Becoming a Person. Boston: Houghton Mifflin.

Rogers, C. R., \& Dymond, R. F. (1954). Psychotherapy and Personality Change. Chicago: University of Chicago Press.

Rogers, C.R. (1951) Client-centered therapy. Boston: Houghton - Mifflin. 
Rooke, D., Torbert, W. (2005). Seven Transformations of Leadership, Harvard Business Review, April.

Roth, G., \& Senge, P. (1996). From Theory to Practice: Research Territory, Processes and Structure at an Organizational Learning Center. Journal of Organizational Change Management 7 (5): 92-106.

Rousseau (1985). Issues of Level in organizational research: Multi-level and cross level perspectives, Research in Organizational Behavior, 7, 1-37.

Ryan, R. M., Brown, W. (2003). Why We Don't Need Self-Esteem: On Fundamental Needs, Contingent Love, and Mindfulness, Psychological Inquiry, 14, 1, 71-77.

Scharmer, C. O. (2007). Theory U: A social technology for leading profound change. Cambridge, MA: SoL Press

Schneider, M., \& Somers, M. (2006). Organizations as complex adaptive systems: Implications of complexity theory for leadership research. The Leadership Quarterly, 17(4), 351-365.

Senge, P., 1990. The fifth discipline. New York: Doubleday. 
Snell, R. S. (2002). The learning organization, sensegiving and psychological contracts:

A Hong Kong case. Organization Studies, 23: 549-569.

Starik, M., \& Rands, G. (1995). Weaving an integrated web: Multilevel and multisystem perspectives of ecologically sustainable organizations. Academy of Management Review, 20(4): 908-935.

Steckler, E. \& Torbert, W. (2010). A "Developmental Action Inquiry" approach to teaching first-, second-, and third-person action research methods. In S. EsbjornHargens, J. Reams \& O. Gunnlaugson (Ed.s) Integral Education: New directions for higher learning. Albany NY: SUNY Press. pp. 105-126.

Strange, J.M., \& Mumford, M.D. (2005). The origins of vision: Effects of reflection, models and analysis, Leadership Quarterly, 16, 121-148

Tellegen, A., \& Atkinson, G. (1974). Openess to absorbing and self-altering experience ("absorption"), a trait related to hypnotic susceptibility. Journal of Abnormal Psychology, 83, 268-277.

Torbert, W. (1994). The power of balance: Transforming self, society, and scientific inquiry. Sage: Newbury Park, CA.

Torbert, W. \& Taylor, S. (2008). Action inquiry: Interweaving multiple qualities of attention for timely action. In P. Reason \& H. Bradbury (Ed.s) The SAGE 
Handbook of Action Research: Participative inquiry and practice (Second Edition). London UK: Sage Publications. pp. 239-251.

Torbert, W. and Associates (2004). Action inquiry: The secret of timely and Transforming leadership. San Francisco, CA: Berrett-Koehler.

Uhl-Bien, M., Marion, R., McKelvey, B., (2007). Complexity Leadership Theory: shifting landscape from the industrial age to the knowledge era, Leadership Quarterly, 18, 298-318.

Waddock, S. (2007). Leadership Integrity in a Fractured World, Academy of Management Learning and Education, 6, 4, 543-557

Waddock, S., (2008). Building a new institutional infrastructure for corporate responsibility. Academy of Management Perspectives, 22 (3): 87-108.

Waldman, D.A., Yammarino, F.J. (1999), CEO Charismatic Leadership: Levels-ofManagement and Levels-of-Analysis Effects, Academy of Management Review, 24, 2, 266-285.

Weick, K. E. (1993). The collapse of sensemaking in organizations: The Mann Gulch disaster. Administrative Science Quarterly, 38: 628-652. 
Weick, K. E. (1995). Sensemaking in organizations. Thousand Oaks, CA: Sage.

Wilber, K., Engler, J., \& Brown, D. (1986) (Eds.), Transformations of consciousness: Conventional and contemplative perspectives on development, Boston, Shambala.

Yukl, G. (1999). An evaluation of conceptual weaknesses in transformational and charismatic leadership theories. Leadership Quarterly, 10, 285-305. 
Figure 1. Executive as Catalyst of Transformation

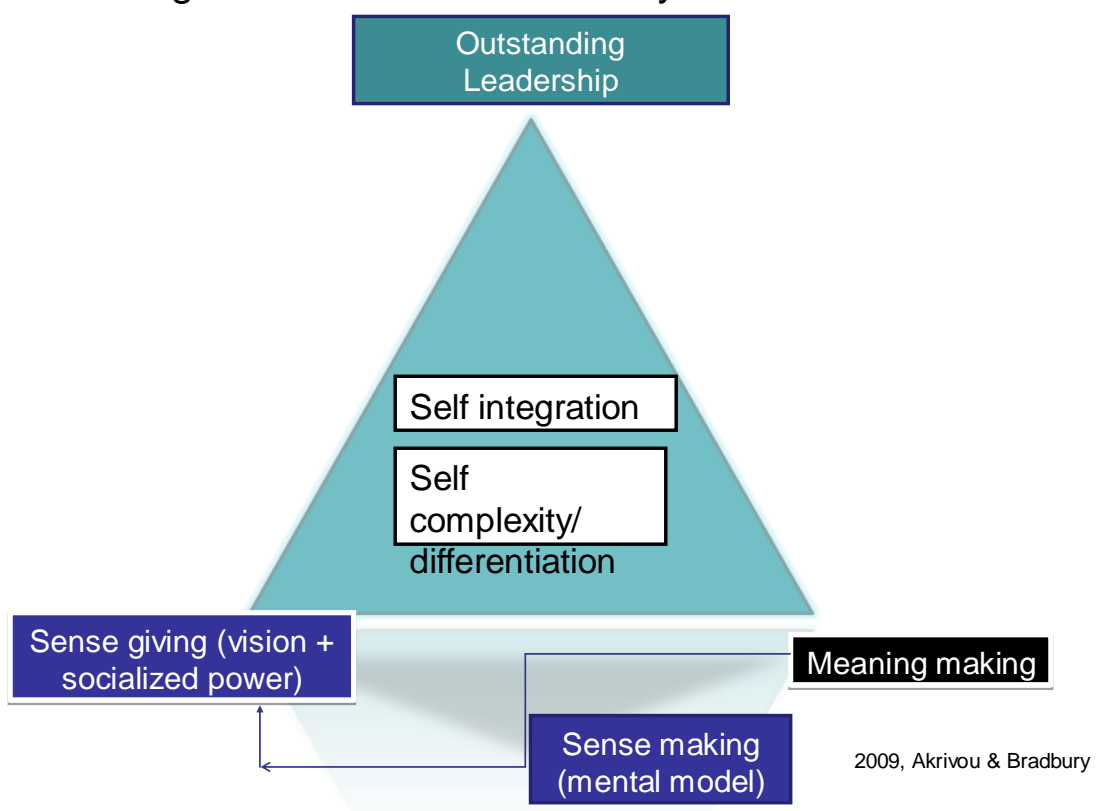


Executive Catalysts: Predicting Sustainable Organizational Performance Amid Complex Demands

Figure 2 - Executive Catalysts Self System Leadership Process Model

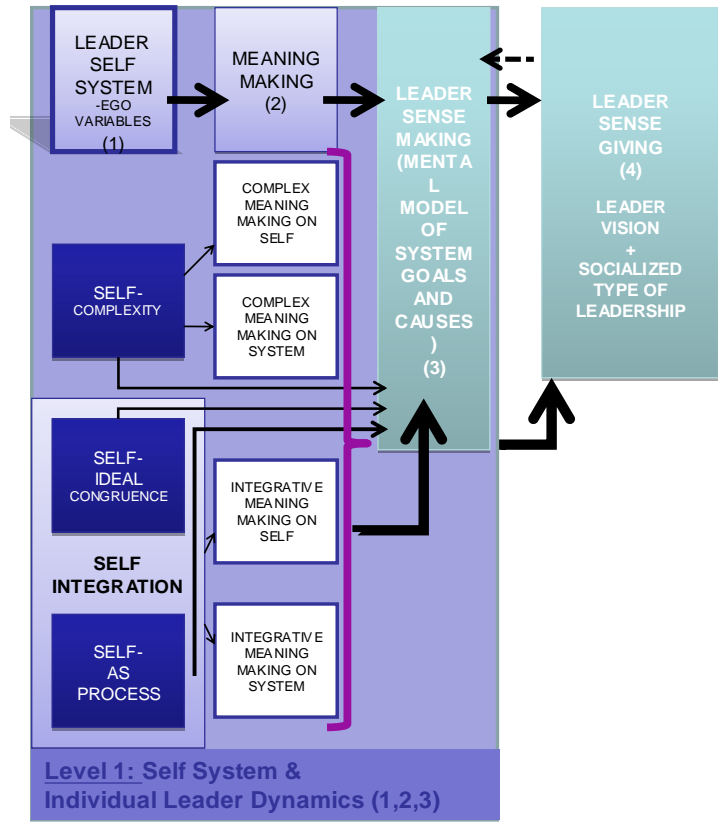

2010, Akrivou \& Bradbury 
Executive Catalysts: Predicting Sustainable Organizational Performance Amid Complex Demands

Figure 3 - Executive Catalysts Process Model \& Dynamics Across Levels

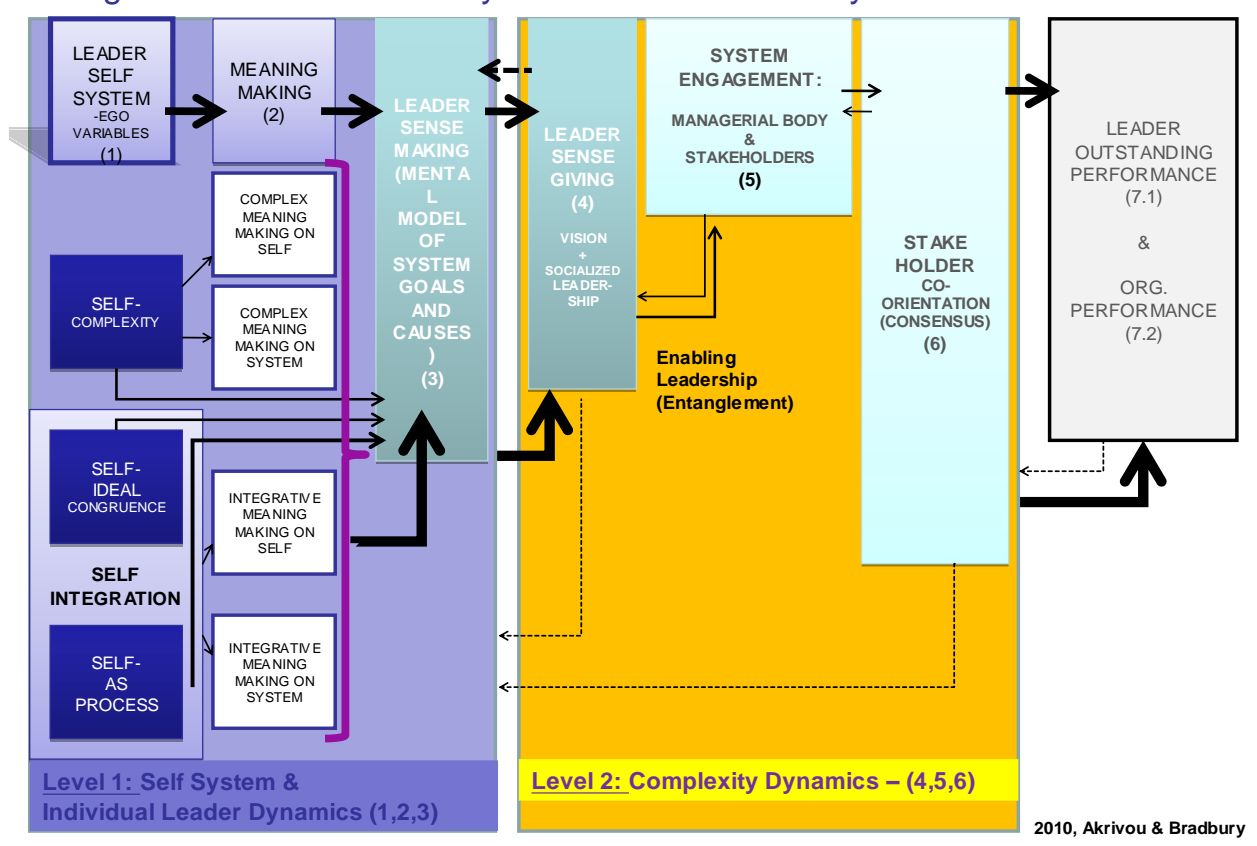

